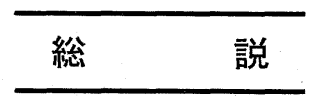

\title{
日本脳炎ウイルスの vector
}

\author{
高，橋 三雄石井孝唐牛良明 \\ THE VECTOR OF JAPANESE ENCEPHALITIS VIRUS
}

\author{
Mitsuo TAKAHASHI \\ National Institute of Health, Tokyo \\ Takashi ISHII \\ Kyoto Prefectural Institute of Public Health, Kyoto \\ Yoshiaki KAROJI \\ Public Health Research Institute of Kyoto City, Kyoto
}

〔受付 : 10月20日，1973年】

第1 部 ウイルスと vector との諸関連

I 、まえがき

II. Vector 個体によるウイルスの増幅

1. 感染の成立

2. Vector 体内でのウイルス增殖

3. 媒介能の成立

III. 流行学的に見た vector

1. Vector の種の問題

2. 吸血習性

3. 日脳流行因子としてのコガタアカイエカ個体 群

第 2 部 コガタアカイエカ個体群の量的把握について の問題点

I 、はじめに

III. コガタアカイエカ個体群の認識と把握方法の不 一致

III. 把握の対象となりうる蚊個体群

IV. 定量的採集方法と採集個体数の変動要因

1. Wわゆる定量的採集法

2. 誘引源と環境要因

3. 採集場所の差

$\mathrm{V}$. 採集データの検討

1. 採集個体数の日変動
2. 全採集個体数の推定

3. 消長曲線の推定

4. Williams' mean

VI. 調查対象個体群の選定

VII.あとがき

日本脑炎ウイルスの vector に関する知見は，かが国 における三田村, 北岡らの一連の研究に端を発して今日 に至るまで著しく進展し, 発表された論文も膨大な数に 達する. しかしながら，仔細にその内容を検討すると， われわれにとって未知の領域が驚く程数多く残されてい ることに気付く.

したがつて本稿においては, 日脳ウイルスの vector に関する研究の 歴史的概括や知見の 網羅を試みるより も，むしろ残された問題点の発掘に重点を置いて解説を 試みることとしたい。

特に1960以来わが国の国公立研究機関や大学で急速に 進められてきた研究成果は，まだ論文という形で公表さ れていない部分がかなりあって，引用文献として適切で ないものも多いが，部分的に㐫えてそれらも引用して あることを断りしたい。

なお，第 1 部胲橋，第 2 部は石井および唐牛が分担 執筆した. 


\section{第 1 部 ウイルスと vector との諸関連}

\section{I. まえがぎ}

蚊媒介性である日脳ウイルスが野外で蚊以外の吸血性 節足動物から分離された例はきわめてまれであり，かつ データとしての信頼性もきわめて薄い.したがって日脳 ウイルスに蚊以外の vector があり得るかといら問題は ここでは扱わない. 万一どこかでそのような事が起こっ ているとしても， ウイルスと vector との関連という点 では，以下の記述に基本的な変更が必要とされるとは考 えにくいからである。

\section{Vector 個体によるウイルスの増幅}

\section{1. 感染の成立}

周知のように，蚊のウイルス感染は viremia の状態に ある宿主 (脊椎動物) からの蚊の吸血を通じてなされる ことが基本的な道筋である.人工的にはウイルスを直接 蚊の体内に注射する方法 ${ }^{11)}$ ，ウイルス液に蚊幼虫を浸す 方法 ${ }^{15)}$ ，ウイルス液に蚊をとまらせて跗節よりウイルス を侵入させる方法13)などで感染を起こさせることができ るが，これらの道筋が没学的な重要性を持つとは考え難 ?.

蚊が動物血液を吸入すると，直ちに蚊の 前部中腸細 胞 (anterior midgut cells) 怯物質の分泌を開始し，血 液はこの物質による膜 (peritrophic membrane) により 周囲を包まれて blood bolus として後部中腸 (posterior midgut）に蓄えられる23). したがつて血液中にウイル スが存在する場合，第 1 感染部位である後部中腸細 胞が直接ウイルスに露出されることがなく, peritrophic membrane（以下 PM と略）の存在は蚊のウイルス感 染に重要な働きをなすことが想定されるが，まだこの PM の役割についての解明は全くなされていない. 螢 光抗体法による土井らての所見によると, コガタアカイ エカの日脳ウイルス感染初期には後部中腸細胞のうちご く限られたものしか特異螢光を示さず, 後次第に全面に ウイルス抗原が行きわたるが，この事は PM の役割を 暗示するものであろう，ウイルス注射法によると，吸血 法に比して蚊のウイルス感受性が著しく高まることが林 ら11)によつて報告されているが，あるいはこれも蚊の中 腸細胞のウイルス感受性だけでは説明できないかも知れ ない.

蚊のウイルス感受性は, 蚊の種類が異なればまた当然 異なる，感受性の定量的表現としては，Gould ら 9 の minimum infective dose（蚊の $5 \%$ 程度を感染せしめ るウイルス量) や Collins らら)の50\% infective level がある，後者の場合は，同一感染ウイルス量に対して蚊
個体の反忘がおそらく正規分布するであろうことを前提 としており，実際にコガタアカイエカと日脳ウイルス JaGAr \#01株との間には用量一反応関係がよく成立し， $50 \%$ 感染量を $10^{1,7}$ マウス致死量と 計算することができ る28). しかしながら，よく整備された実験条件でのこの 種の定量的観察は現在でもきわめて不足しており，各種 類の蚊の日脳ウイルスに対する感受性の定量的比較や， 同一の蚊に対するウイルス株の感染性の比較が十分行な われたとは言い難い.

実験室内で弱毒化された日脳ウイルス株は，一方コガ タアカイエカに対する感染性を低下させるかまたは失つ ていることが報告されている6299が，この事実は注目さ るべきとしても，その機序に至るまでは解明されていな ฟ.

\section{Vector 体内でのウイルス増殖}

ウイルスを感染させた蚊を高温（通常は $27-30^{\circ} \mathrm{C}$ ) で 飼育し，経日的に蚊個体のウイルス量を測定すると，感 染後10-14日でウイルス量は最高值に達し，その後は蚊 の生存期間を通じて見かけ上 plateau の状態でウイル スが保持され続ける10228)。しかし，蚊体内でのウイルス 生産の dynamics はかなり複雑であつて，われわれの 知識はまだきわめて概念的である.

LaMotte ${ }^{16)}$ および土井ら7によつて調べられた蚊体内 のウイルスの消長を通覽すると次のようである.

第 1 の感染(増殖)部位である中腸細胞では，感染の後 期になるとむしろウイルス量が低下する，中腸細胞がウ イルス感染によつて傷害を受けずにウイルスの供給力を 失つて行く機構については全く不明である. インターフ エロンないしは類似のウイルス増殖抑制物質の産生が, 予想されるが，まだ想定の域を出ない．奈須ら21)の電顕 所見では，この部位がウイルスの multiplication form を認め得た唯一の場所である(第 1 図).

ウイルスの第 2 の主要な増殖部位としては，体内のあ ちこちに分布する脂肪産生組織が重要な働きをするであ ろうことはほぼ疑いない，特に，後述するように，唾腺 の先端を取り巻く脂肪産生細胞の役割りはきわめて大き いと考えられる.

血りンパは当然ウイルスの transport に関与するであ ろうが，その様式については全くわかつていない. Phagocytic cell などの血球部分や蚊の active lipid transport とウイルス transport との関係について今後精査 する必要がある。

哺乳類に対して好神経性である日脳ウイルスが，蚊に 対して特に著しく好神経性を示さない点は興味ある事実 である，感染のきわめて後期には，頭部および胸部神経 節に高いウイルス量の集積を LaMotte は認めている 


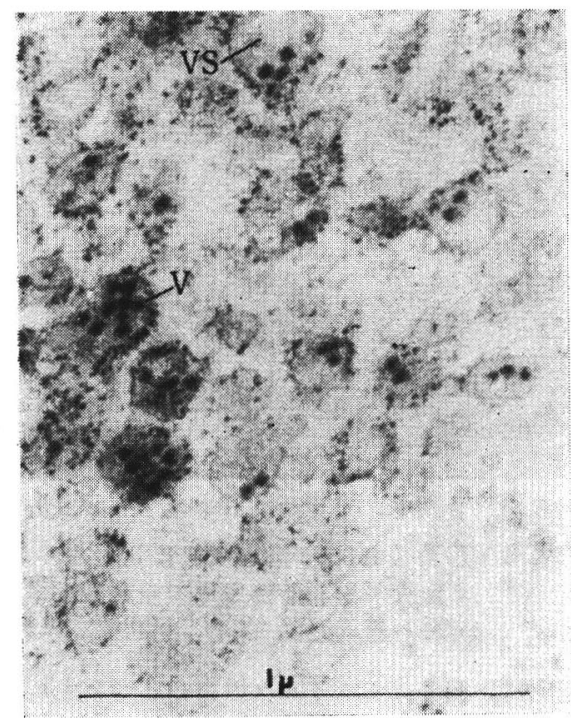

第 1 図日脳ウイルス感染コガタアカイエカ中 腸表皮細胞に抢けるVesicle (VS) 中 のウイルス (V) 成熟（奈須，北岡， 高橋）（原図）

が，螢光抗体法による土井らの観察ではそれ程の重要性 を認めていないようである.

その他の諸蔵器については, 唾腺を除いてはウイルス 増殖部位として注目されるものは特に見当たらない.

唾腺は，中腸や脂肪産生組織と並んで，蚊のウイルス 感染にとつてきわめて特異な役割を果たすが，その詳細 は次節にゆずることとする.

3. 媒介能の成立

非常に特殊で，かつ例外的な場合には，蚊が高濃度の ウイルスを含む血液をある宿主の個体から部分的に吸血 し，污染された口吻で直ちに他の個体への吸血に移るこ とによつて, 後者へのウイルスの mechanical transmission を起こすことも想定されるが4)，日脳ウイルス を含むアルボウイルスの媒介様式は基本的には biological transmission である。

コガタアカイエカに日脳ウイルスを感染させると，や がて唾腺に高濃度のウイルスの集積が起こり，特に喠腺 細胞の液胞（唾液）中にそれが著しいことが前記土井論 文7にも示されている。唾液のウイルス濃度は最終的に は蚊 1 個体の吸血に伴う排出唾液量当たり $10^{4.0}$ マウス致 死量にも達する ${ }^{28)}$. 唾液全体のウイルス量も比較的早く 中腸のウイルス量を凌駕する(第 2 図)。

問題は唾液中へのこのような大量のウイルス集積の機 序であつて, 奈須ら ${ }^{21)}$ 電影的所見ではコガタアカイエ カ唾腺中のウイルスは液胞内の大量の virion の集合と して認められるが，唾腺細胞の cytoplasm にはこれら

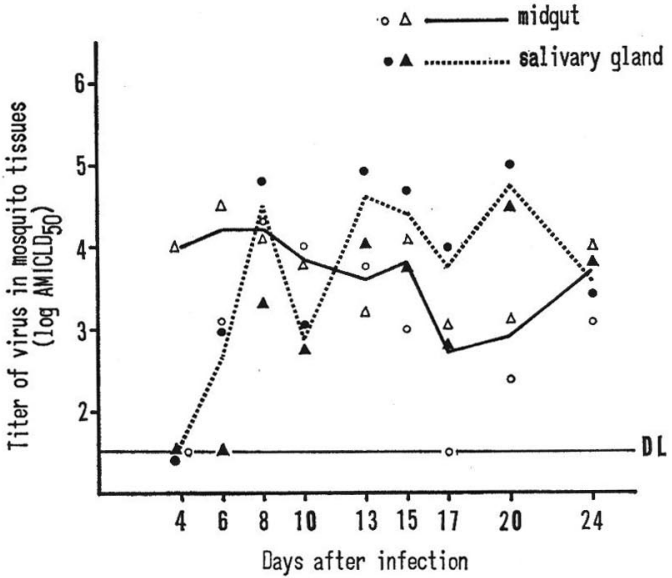

第2図コガタアカイエカ中腸㧍よび唾腺の日 脳ウイルス量の変動(高橋, 原図) DLdetectable level

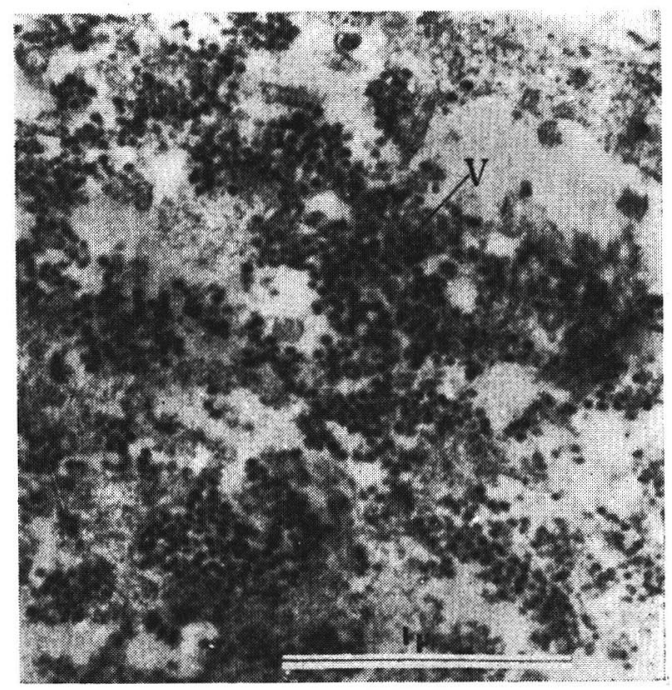

第 3 図 日脳ウイルス感染コガタアカイエカ唾 腺液胞中へのウイルス粒子 (V) の集 積 (奈須, 北岡，高橋) (原図)

の源となるようなウイルスの増殖像を発見していない (第 3 図)．A群に属するアルボウイルスでは唾腺細胞内 でのウイルス増殖像が電顕的に認められるとの報告があ る12)37)が，これが唾液中のウイルスを供給するのに十分 なものであるかどうかはわからない，睡液中のウイルス が他から機械的（または生物学的）に取り込まれるので はないかとの疑いを生ぜしめる理由は他にもある，

第 1 に，蚊体内でのウイルス増殖はかなり単純に温度 依存的であつて，10ㄷ になると增殖が停止する17が， 媒介能の発現は必す゚しももウイルス増殖と平行でなく， 低い温度条件では媒介能の成立が著しく抑制されるとい うことである. 第 4 図は蚊に高い濃度のウイルスを吸わ 

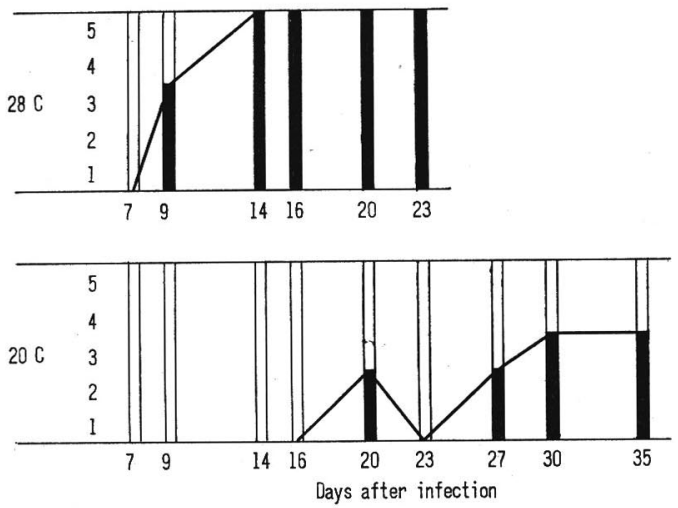

第 4 図 2 つの温度条件下でのコガタアカイエ カの日脳ウイルス媒介能発現（高橋， 原図)。綐軸は各日に 5 匹の蚊を使用 し，黒ぬりの部分の数だけ媒介能十で あることを示す

せ， $100 \%$ 感染率を 示す状態で $2 つ$ 温度 $\left(28^{\circ} \mathrm{C}\right.$, $\left.20^{\circ} \mathrm{C}\right)$ 条件での蚊の ウイルス媒介率を比較したもので あるが，低、温度では感染後35日を経過しても媒介率が 100\%に達しないことを示したものである，螢光抗体法 でこのような蚊の唾腺の部分を観察すると, 唾腺周囲の 脂肪産生細胞にまで注特異螢光が到達しているが，唾腺 内部にはウイルスが入り込んでいない像が観察されるこ とがある。したがつて低温条件でのウイルス媒介能成立 の抑制は棰腺の何らかの生理的不活性と関係があるらし いことが想定された ${ }^{311}$.

次に, 蚊のウイルス媒介能は蚊の個体としての生理活 性と関倸があるらしいといらことである。日長条件を異 にして蚊を飼育した場合, 短日に置かれた蚊の唾液中の ウイルス濃度は長日に置かれたものよりも低いといら報 告がある3．ただしこの論文では，長日に置かれた蚊の 唾液のウイルス濃度そのものがかなり低いので，十分信 頼性を置けるデータではないかも知れない.

いずれにしても, 将来コガタアカイエカ唾腺でのウイ ルス増殖が電顕や他の方法で証明されることがあり得る としても，それで上記の疑問が氷解するわけではない.

唾腺以外の場所から唾液にウイルスを供給する場所が あるとすれば，それはおそらく唾腺の先端部分を広く取 り巻いている脂肪産生組織であろう。第 5 図に示した螢 光抗体の写真でも明らかなように，この細胞群には著明 な特異螢光が例外なしに観察される。この脂肪体の役割 については不明であるが，唾腺に対する物質やエネルギ 一供給に役立つであるうことは十分考えられるから，こ の場で産生されるウイルスが唾腺（または唾液）と何ら かの関係を持っであろうことを予想しても誤りはないで あろう。

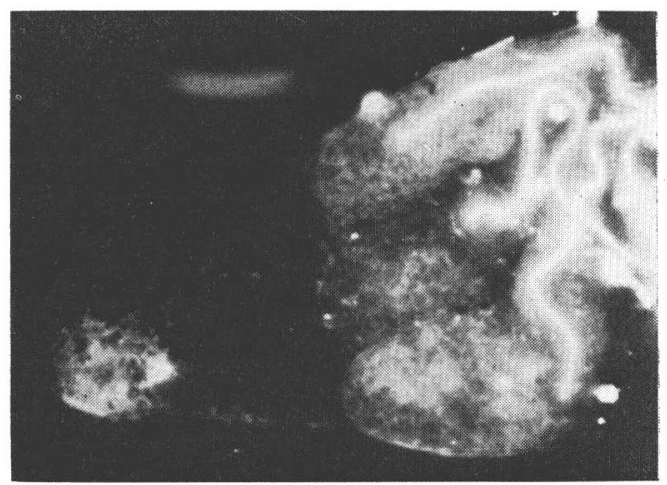

第 5 図日脳ウイルス感染コガタアカイエカ在 腺の溃光抗体写真. 唾腺の 3 本の lobe そ, 先端部脂肪体左端の脂肪産生細胞 に強、特異螢光を示す．（高橋，原図）

液胞内に集積されるウイルスの運命についても疑問の 点が少なくない，温度条件としては外気依存的であり， 液胞という環境条件の中で果たしてどれだけ感染性を保 ち得るのか，また常に彼らは新しい粒子に補填されるこ とによつて全体の感染価を維持しているのかについても われわれは知識を持たない。

\section{III. 流行学的にみた vector}

\section{Vector の種の問題}

わが国においては, 野外で採集された蚊からのウイル ス分離の結果を見ると，日脳ウイルスに関する限りほと んどがコガタアカイエカからであり，例外は非常に少な (38). 日本産のコガタアカイエカは, 通常 Culex tritaeniorhynchus summorosus と呼ばれる亜種に属し， この亜種の分布範囲はインド，パキスタンで原亜種 $C$. t. tritaeniorhynchus と境を接してその東，すなわち東 南アジア，インドシナ，インドネシア，フィリピン，中 国, 朝鮮, 日本, 沿海州などに分布しており，日脳ウイ ルスの分布領域ときわめてよく一致している28)．しかし 分類学的には最近では原種と summorosus 亜種とを識 別する形態学的特徴が非常に変異の多いことから summorosus 业種の独立性はむしろ否定されている22. Barnett は両者の交雑実験によつて, パキスタン産の C. $t$. tritaeniorhynchus の雌と日本産の C. t. summorosus の雄とを交配させた場合には受精率が低いことを述べて いるが1)，このような遺伝的な性質は亜種としての違い を示すものでなく、コガタアカイエカの狭所交尾性 （stenogamy）を規定する遺伝因子の実験に使用した population の間の差異を表言したものに過ぎないと考 えてよいであろう26).

日本以外では，台湾では Culex annulus ${ }^{222}$ が，ボル 
ネオでは Culex gelidus ${ }^{18)}$ が main vector であると考 えられ，これらの地域ではコガタアカイエカに比べて数 量的にもこのような種類の蚊が diminant であると考え られる.

日本でのコガタアカイエカ以外からの分離例では，特 にアカイエカが注目され，このような蚊が流行学的（ま たはウイルスの生態学的）にコガタアカイエカと異なつ た役割を果たしているのではないかと想定される場合も あるが確証を欠く。

\section{2. 吸血習性}

流行学的な立場から見ると, 蚊の吸血習性（動物啫好 性) は vector と hostとの閒のウイルスの授受を左右 する因子としてきわめて重要である. コガタアカイエカ はブタやうしなどの大動物からよく吸血し，また人閒を も好んで襲うことから，日脳ウイルスの主要な amplifier であるブタや，また直接人閒に対するウイルスの伝播者 として生態学的にも main vector としての地位を保つ. 特に日脳ウイルスの reservoir としてコウモリ，トカ ゲ，カエルなどの特殊な動物が注目されるようになる と, 一層これらの動物に対する蚊の吸血性が論ぜられざ るを得ない.

一般に蚊の吸血習性を解析する手段としては，

イ. 人工的に設置された動物に飛来し, 吸血する蚊を 観察する.

ロ. 同様に動物を置いた籠の中に各種の蚊を放つて吸 血率を比較する.

八. 野外で吸血した蚊を採集し, 免疫学的その他の手 段により血液の同定を行なう。

の三法が採られる.

Scherer ら 25$)$ animal bait trap 中に飛来した蚊 を観察することによつて，コガタアカイエカがブタとゴ イサギに高い嗜好性を持つことを見てこれらの動物が日 脳ウイルスの amplifier として重要であることを証明す る一手段とした．また宮城201は，諸種の冷血動物を用い て16種の蚊の吸血性を上記口の方法によつて比較した. このような例は一方では貴重な知見をわれわれにもたら すものではあるが，他方ではまた誤つた概念をもたらす 危険を含んでいると思われる。すなわち，イの方法では かなり蚊の自然の吸血行動を反映するものであるが，特 に小型の動物種を用いた吸血場所の設定が困難であり， 実験が全く失敗に終ることが多や，また蚊の吸血習性が 蚊の側だけの要因で決まるものでなく，host 側の要因 も関与することが知られ，ゴイサギが蚊の吸血行動を忌 避する anti-mosquito behevior を持たないことから蚊 の攻撃を受けやすく8，また実際に野外でも多種の蚊 から吸血されていることが知られているが30)，前述の
Scherer らの実験ではこの観点が見逃されている.

また口の方法では，得られたデータはかなり良く実際 の吸血性と平行するように思われるが, 人工的に隔絶さ れたスペースと吸血源という条件の中で，ある種の蚊の 吸血習性がプラスの方向へ不当に拡大されて評価される おそれがある。

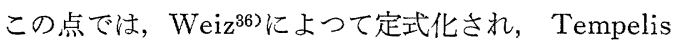
ら ${ }^{33}$ によつて発展させられた第 3 の方法は蚊の実際の吸 血性を正確に反映するものであり，沈降反応に使用する 抗血性も哺乳類に対しては科 (Family), 鳥類に対して は目（Order）に特異的なものを容易に作製することが できるが32)，この方法の最大の難点と言えることは野外 で免疫反応に利用できる程未消化の血液を持つた蚊を, 特定の吸血源の影響なしに大量に捕獲することがきわめ て困難な点にある。

日脳ウイルスの生態に関連させて蚊の吸血習性を論じ た報告は，あまねく引用すれば数多くあるが，それにし ても未知の分野が多い. 日脳ウイルスが冬期に分離され たというコウモリ27ををどのような蚊がどれだけ吸血して いるかということは全く判つていない. トカゲやカエル などの泠血動物をコガタアカイエカが実際にどれだけ吸 血するかも，現在までの知見では不足である. 多くのア ルボウイルスの host であることが知られる野鳥類に対 する蚊の嗜好性が客観的なデータとして示された事は少 ない.この分野での知識を得る仕事は今後も大規模に進 められる必要があろう.

3. 日脳流行因子としてのコガタアカイエカ個体群 近年のわが国における日本脳炎低流行の原因として, vector であるコガタアカイエカの減少によるものであ ることが研究者の閒でも確認されている．媒介蚊の個体 群と amplifier であるブタの個体群との関係から日本脳 炎の流行過程を理論モデル化する試みが佐々24) と和 田3435)によつてなされた. 特に後者では, 流行が起こら ないための蚊およびブタの限界密度について触れ，ブタ (免疫豚) の限界密度もまた蚊の密度に 依存的であるこ とを示した．また前田ら ${ }^{19)}$ は京都における成績から，各 年の蚊の発生指数と患者発生数との間に高い相関が見ら れることを報告した.

日本脳炎のように不顕性感染率が高く，また近年のよ うな低流行である疾病について，流行の変動要因を直接 患者数と結び付汀て解析寸ることは多分に無理があるよ らに思われるが，媒介蚊の個体群と流行との疫学的関連 についてはさらに今まで提出されたモデルを補強し，完 成させて行くことが必要である.

一方, 媒介蚊個体群の変動要因については, その理解 を得るには一層障害が大きい. コガタアカイエカの主要 
な発生水域である水田をコントロールするには医学者 は，農学者の緊密な協力を得ることなしには，到底無力 であつて, われわれは水田稲作の技術の歴史的な変遷が 結果的にコガタアカイエカの動態にどのような変化を与 えたかを知るのみの結果に終わつている.

総合防除の立場からのこの分野での農学者之医学者と の提携はまだきわめて部分的であつて, 研究体制の上で の見るべき発展はない.

コガタアカイエカ発生減少については，上村ら ${ }^{14)}$ は農 業形態の近代化にその理由を求めた. また和歌山県の研 究者は水田農薬が DDT や BHC などの塩素系殺虫剤 から有機燐系ないしカーバメイト系殺虫片一切り換えら れたことが蚊を減少させる原因となつたことを示唆した (未発表). 気象条件の影響や都市化倠よる都市近郊水田 の水質污染は, 論議されることはあつてもそれが蚊の発 生とどのような関連があるかを因果関係として提示され るには根拠にとぼしい。

いずれにしても，水田におけるコガタアカイエカの動 態とその人為的なコントロールについて個体群生態学的 な追究がなされるべきである.

また蚊の場合には, 幼虫と成虫が全く異なつた生態的 地位を占めるから, 個体群の把握には当然異なつた手段 が要求される. 成虫個体群の把握についても新しく検証 され直さ叔ばならない点が少なくない．

以下, 第 2 部においては，この点についての問題点を 論述することとする.

\section{第 2 部 コガタアカイエカ個体群の量的把握に ついての問題点}

\section{I.はじめに}

日本脳炎ウイルスの動向を理解するためには，日本脳 炎ウイルスの感染系への導入や増幅, 伝播を量的に把握 することが必要であるう。このうち，伝播の過程は，大 部分コガタアカイエカによつてなされていると考えられ るから, 日本脳炎ウイルスの生態を, コガタアカイエカ の個体群の動態と関連づけて理解しようとする試みがさ れているのは，ごく当然の成行きであろう24).

しかし，これまでに数多くの研究が行なわれたにもか かわらず，この試みは必ずしも成功していない，それど ころか, 日本脳炎患者発生数や之場豚の HI 抗体保有状 況などと，無反省にとられたコガタアカイエカの発生動 態を比較することによつて，混乱をひき起こしているよ うにさえ思われる。

蚊の個体群を把握する試みは, 日本脳炎研究史の中に 限つてみても, 約 40 年の歴史をむつが, 第 2 部では, コ ガタアカイエカ踓成虫個体群に対する認識と把握方法の
変遷を振り返りつつ，これらに関するいくつかの問題点 を浮き彫りにしてみたい.

なお，限られた紙数の中で，このような問題を多方面 から検討することはできないので, ここでは文献を網羅 しょうとせず，最小限の引用にとどめ問題を概括した ᄂ.

\section{II. コガタアカイエカ個体群の認識と把握方 法の不一致}

日本脳炎ウイルスが，蚊とくにコガタアカイエカによ つて媒介されることを最初に示唆した山田 ${ }^{333}$ は，その当 時から, 蚊の個体数と日本脳炎患者発生の消長を関連う けて考えている. 彼は, 蚊の 1 つの“繁栄の山”之患者 発生数の“ 1 つの山”との間に約 2 週間の隔りがみられ ることを明らかにしたが，この“繁栄の山”は，後に 「山田の頂」と呼ばれ22), 以来，これら 2 つの山に関す る関連性は, 多くの研究者によつて論じられた. たとえ ば，Buescher ら》はこれらの関連性よりも，有毒蚊の

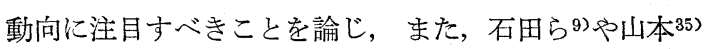
は，新知見をまじえながら再検討して話題を呼びおこし た.

これらの研究は, 蚊個体群の動向と日本脳炎患者発生 あるいは日本脳炎ウイルスの生態とを関連づける上で, マイル・ストーン的存在であるといえようが，はたし て, 彼らが研究の対象とした蚊個体群そのものには統一 性が見い出せるだろらか.

いま，彼らの用いた蚊の採集方法をみると，山田 ${ }^{34)}$ 食堂とベランダで蚊遣り香の燻蒸でとらえた数種類の蚊 をとらえ，三田村223 は，学生集会所の休止中の蚊を 網 筒により, Buescher らては ベイト・トラップ (ベイト は鳥, 豚, 人など）により, 石田ら92は, 豚舎につけた 畜舎トラップにより，また，山本 ${ }^{35)}$ はライト・トラップ などいくつかの方法でコガタアカイエカを採集してい る.また，採集の間隔についても，連日採集のものか ら，週 $1 \sim 2$ 回というようにまちまちである.

以上のように, 時間帯, 場所, 方法, 間隔を異にして 採集された蚊個体群は, 少数の例外を除いてすべて媒介 蚊の個体群として理解され, 暗黙のうちに同一の対象と して論じられてきたように思われる，そこで，これらの 各研究者の結論を比較する前に, 各研究者のとらえた蚊 個体群に共通性があるかどうか考える必要がある.

\section{III. 把握の対象となりうる蚊個体群}

いま, 蚊個体群を, ある時点にある地域内に生息する すべての蚊成虫の集団と定義するならば，現在のとこ ろ，どのような方法でもこのような野外個体群を代表す 
るサンプルをとることはできない5). このことをコガタ アカイエカについて考えれば，この蚊の生活史のなかに は，羽化直後と吸血後の休止期など，飛翔活動を行なわ ない時があり37)，この期の蚊は各種の誘引トラップで捕 集されないし，一方，休止場所は多岐にわたるので，休 止蚊は部分的には, 捕虫網, 吸血管, 吸虫機により採集 され15300)ても，全体の集団を把握するには十分でないか らである.

したがつて，これまで論じられてきた蚊個体群は，多 くの場合, 部分的なもの, それも, 飛翔活動を積極的に 行なう時期か，吸血直後などで人の目にとまりやすい個 体群であつたと考えてよい.

日本脳炎の研究と関連づけて考えるとき，上のような 捕えやすい蚊だけを集めて, これを対象とすべき蚊個体 群とすること自体多くの問題があ万らが，この問題はこ こでは触れないこととして，次に，そのような個体群を “定量的に”把握することにともなういくつかの問題を 考えてみたい.

\section{IV. 定量的採集方法と採集個体数の变動要因}

\section{1. いわゆる定量的採集法}

研究対象の個体群を特殊化することは避けられない が，その個体群を採集するとき，採集効率淿人為的要因 が大りすぎると，採集基礎データそのものが，対象とす る個体群を忠実に反映しているとは言い難い。たとえ ば，休止蚊を網筒222や吸虫管で採集する場合や豚舎に飛 来した蚊をスィーピング法で採集する場合には，採集者 間の能力差や採集作業の微妙な相違が採集結果に大きく 影響するので，よ活どの注意が払われない限り，それら のデータを基にして相対的密度を詳細汇論ずることはで きない。

そこで，人為的要因がなるべく入り込まない採集方法 がいくつか考案された.このうち，日本の研究者に多く 用いられてきたものは, 加藤ら ${ }^{16)}$ の畜舎トラップ (加藤 式トラップといわれている), 各種のライト・トラップ (戦後しばらくはニュージャージー型36)が多く使われた が，最近は野沢式捕虫機が多い)，ドライアイス・トラ ップ17で，この他に，ライト・トラップとドライアイ ス・トラップの併用型なども種々考案されている.

これらのトラップは，セットしてから採集を終了する まで，人の手を借りずに作動して，標本を保存しうる構 造になつているので, 採集者の能力などに関係なく, 定 量的な採集が行ないらるとされ，得られた採集結果につ いては無反省に“定量的採集”としての取扱いがなされ てきたきらいがある。しかし，トラップによる採集個体 数に影響を及ぼす変動要因は予想外に多く2)，これらを
見極めないと“定量的に採集”した結果の意味づけがで きないことがしだいに明らかになり4，“定量的採集結 果”すなわち蚊個体群の動向の定量的把握と考えると一 種の楩穴にはまり込む危険があることが明らかになつて きた.このことにういて，次仯し詳しくみてみたい。

\section{2. 誘引源と環境要因}

同一型のトラップを 2 個以上用いて採集し，結果を比 較する場合には，誘引源の誘引力を定格化する必要があ る. たとえば，ライト・トラップの光源が異なると，誘 引される昆虫の種類, 相が異なることは，一般に知られ

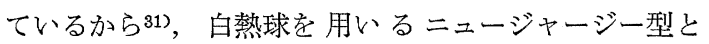
BLB 螢光管を用いる野沢型による採集結果をそのまま 比較することができないことはむちろんであるが，同一 型の光源であつても, 光の強さが異なれば採集効率に影 響を及ぼすから1)，螢光管の新旧による差の影響にも注 意が払われるべきであろう。また，ライト・トラップの 場合, 付近の光や月光が 予想以上に採集効率に影響す る3221)から，採集個体数は月令と月明の時間（時間带も 含めて）によつて補正されなければ, 調查対象集団の個

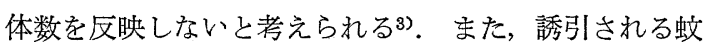
は吸血のために飛来するものが大部分と思われるが，吸 血行動は環境要因により影響される32).

誘引源として動物を用いる場合, 動物の種類によつ て，採集される蚊の種類，数が異なること注常識とされ ている(しかし，かが国に括いては厳密な選択実験によ る検討は意外に少なく, この点について未解決の問題が 多い)が，同一種を用いた場合にも，ベイトの個体差(品 種，年齞，飼有方法などによる）と個体数の多少が，ど の程度採集効率に影響するか注意が払われていない，実 際に豚舎で採集する場合，経験的には，とれやすい豚舎 ととれにくい豚舎が区別できるが，これらが上に述べた ようなベイトの差（繁殖豚と肥育豚など）に基づくもの であるか，豚舎のおかれた環境によるものであるか明ら かでない、いずれにしても，現時点では，同一種のベイ トを用いたトラップ間の比較であつても，その差をすべ て地域差とすることはできない。

ドライ・アイスを誘引源とする場合には，ドライアイ スの単位時間当たりの気化量が誘引する蚊の個体数と種 類に影響を及ぼす25)が，わが国における調查では，この ことにあまり注意がむけられていない。

複数の誘引源（たとえばドライアイスと光）を用いた 場合の採集効率についてのくわしい仕事はないが，単な る付加的とは考元らないので29)，この結果を単一の誘 引源による結果と並列に比較することは危険である。

各種トラップ間の採集結果を比較する必要性は今後ま すます増大寸ると思われるので，わが国においても 
$8 \quad(180)$

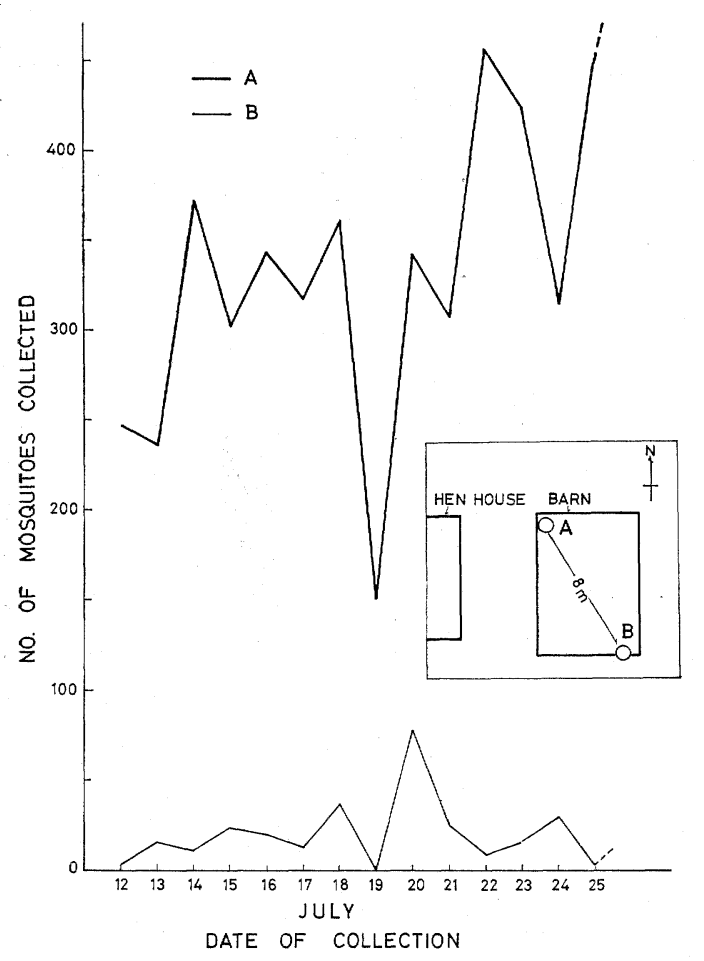

第 6 図鷂舎に近接した納屋の軒下につけた， 2 つの野沢式ライト・トラップ(A, B) による、コガタアカイエカ(雌)採集個 体数の変動(京都市嵯峨野. 1970). わ ずか $8 \mathrm{~m}$ 離れた場所であっても，採 集個体数が異なるばかりか，日変動に も大きな違いがみられる

Bidlingmayer(やなどが試みているようなトラップ間比 較819223262828)や上にあげたトラップ以外のトラップ（た とえばマレイズ・トラップ6), サクション・トラップ'15)30) トラック・トラップ27など）による採集結果の比較が必 要であろう.

\section{3. 採集場所の差}

ごく近接した場所に同一型のトラップを設置した場合 でも，トラップ間で大きな差が得られることは，野外調 查の経験のある者にはよく知られていることである. し かし，そのような結果を示す資料はあまり公表されてい ない，このことは，1つには，そのような資料の公表 は, 自らとつている資料の不確実さを示すようなもので あり，また，データの解釈に混乱をきたすものと考えら れるためかむしれない。

第 6 図は，われわれが京都市嵯峨野の鶏舎付近で, 野沢 式トラップを図のような位置で採集した例である。この 結果をみると，トラップ間で採集された個体数やその日 ३の変動は予想以上に大きいと考えられる. 第 7 図は図
孝・唐牛良明

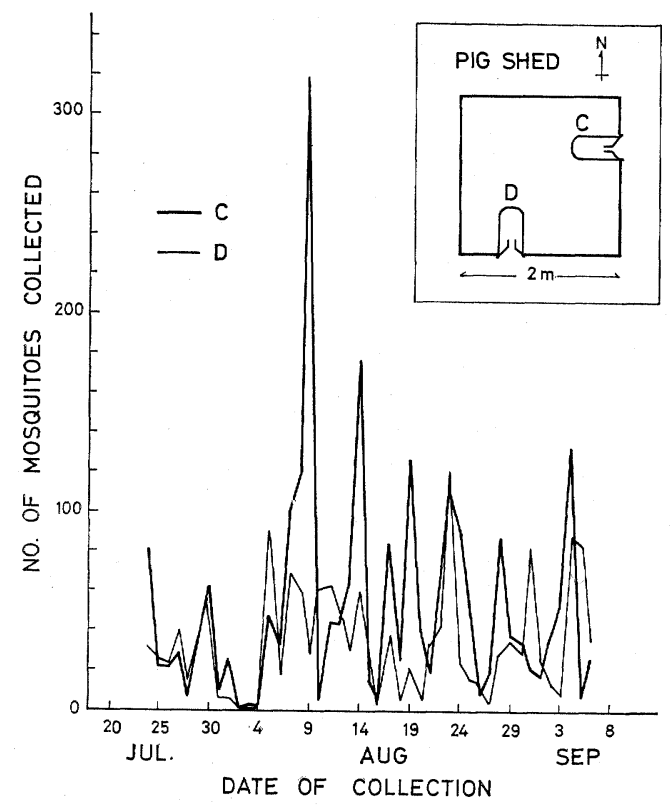

第 7 図，同一の実験豚舎 (肥育豚 1 頭飼育) 江之 りつけた，2つの加藤式トラップ (C, D）による、コガタアカイエカ(雌) 採 集個体数の変動(京都市向代, 1971). 採集個体数が極似する日と, 非常にか け離れた日がみられる

のように同一豚舎の異なる空に取りつけた加藤式トラッ プによる採集結果の一部であるが，これによつても，同 一豚舎で同一型のトラップで採集しても差が大きい場合 のあることがわかる，したがつて，トラップ間で，採集 個体数や種類構成に差が得られたとしてむ，それをトラ ップの設置してある場所閒の差であると速断するのは危 険である.

このように，1個のトラップによる採集結果は，採集 をいかに注意しつつ行なつても, ある地城（部落, 市町 村，県など）を代表する蚊個体群とみなせる結果とはな り得ないから，その採集結果から得られた蚊発生消長 を, 県単位でまとめた患者発生や豚の HI 抗体保有率 の消長と比較しうる (14)35)根拠はそしいし，このような 蚊発生消長資料から採集最多日, 最多数などを地域の差 として論ずる13)ことの意味む薄い(このことには採集間 隔の問題む含まれる．このことについては後に論ずる).

したがつて，ある地域に和ける蚊個体群の動向を知る ためには，少なくとも現在わが国でとられている資料は 不十分である。 その解決策としては，一部に試みられて いるように, 数種類のトラップを調査地域に設置し, そ れらの採集結果から, 加重平均的な值を求める方法など が有効かもしれない．この点については今後の研究が必 
要である.

\section{V. 採集データの検討}

蚊個体群の動向をトラップによる採集個体数から推定 するためには，その基礎データとなる個々のトラップの 採集結果について，よく吟味しておく必要がある。ここ では，単一トラップの採集方法の差によるデータの信頼 性について考えたい.

\section{1. 採集個体数の日変動}

いずれの型のトラップを用いても，採集個体数の日変 動は図 6 と 7 にも示されているようにかなり大きい10). この変動要因は明らかでないが,環境条件（温度，湿度， 風速など）や蚊の生活史中の活動性のサイクル（羽化 時期，移動期など）によるものであろう、いずれにして も，その要因が明らかでなく，また，変動に周期性など 規則性がみられないので，現在のところ変動の様相を予 知して採集計画を立てることは不可能である.

\section{2. 全採集個体数の推定}

このような場合, 非連続的な採集を行なう（たとえば， 週 3 白採集するなど）ことは，採集個体数の変動と無関 係に，有限採集回数の中から任意に $\mathrm{n}$ 回の採集を行な つたことと考えてよいから，非連続的採集を行なつて得 られた資料を基にして，全採集個体数の推定を行なうこ とができる.

この計算方法としては，いろいろ考えられるが，われ われは，後に述べる消長曲線作成の場合の便宜を考え て，週単位の平均採集個体数（これを trap index とい う）の推計を行ない, trap index の年間総和を collection index として，これをもつて全採集個体数の推 定值を示す指数とした. これら指数の推定值誤差は，そ の例を表 1 に示すように，採集回数が多い程小さくなる が，その大きさは採集地点，蚊の種類によつて異なつて いる.このような採集頻度と採集個体数の信頼性につい ては，これまで等閑視されてきたが，今後より一層注意 する必要がある。

\section{3. 消長曲線の推定}

非連続採集結果をプロットして消長曲線を書く場合, これまでは単位期閒の採集合計数（または平均值）を単 に点を線で結ぶか, それらの採集総個体数に対する割合 について「百分率法」による信頼限界を入れて消長曲線 の変動幅を示す方法がとられてきた ${ }^{18)}$.

このうち，単に点を線で結ぶ方法は，それらの值が， 単位期間の代表值となりうるかどうか判断の規準がない から，意味がないばかりか，蚊の消長様相を誤解させ ることにもなりかねない，また「百分率法」による信頼 限界もこの場合には，その方法を適用するための前提条
表 1

\begin{tabular}{r|c|r|r|r|r}
\hline $\mathrm{Q}$ & 2 & 4 & 7 & \multicolumn{1}{c|}{14} & \multicolumn{1}{c}{18} \\
\hline 1 & 12.9 & 25.2 & 41.6 & 100.8 & 150.1 \\
2 & & 13.8 & 24.2 & 50.9 & 61.5 \\
3 & & 7.8 & 17.2 & 37.0 & 43.6 \\
6 & & & 5.9 & 21.0 & 25.2 \\
13 & & & & 4.0 & 10.5 \\
17 & & & & & 4.1 \\
\end{tabular}

採集期間 $Z$ 日内で， $Q$ 日ずっ L個の採集小期間を 区分し， $Q$ 日中q日採集を行なって得られる Collection index の推定值の相対誤差 $\mathcal{E}(\%)$, (Ig 法に より計算した值)。基礎データは，宇治市大久保に ある開放的な豚舎で，1971年夏に，野沢式ライト・ トラップにより，56日間連続採集して得られた，コ ガタアカイエカ(雌) 個体数.

件がみたされていないから不適当である（これについて の詳しい説明は省略するが，この場合総採集個体数が多 くなればなる程，信頼限界は小さくなり，総個体数が 10000にもなるとその幅は線の太さでも表わせないくら いになり，実際には点を線で結んだと同じである。しか し総個体数が多くなっても，実際には日変動は小さくな らない).

採集頻度と消長曲線の信頼性について Loomis and Hanks ${ }^{20}$ ) 潩なる採集頻度で得られたトラップ・イン デックス閒の相関係数の大きさから，Culex tarsalis に ついて週 3 日採集で十分であるとした. 石井 ${ }^{111}$ は彼らと 同じ方法でコガタアカイエカについて調べ同様な結果を 得たが，この場合，得られた相関係数の大きさから，消 長曲線の信頼性を論ずることができるかどうか問題であ ろう。.また，トラップ・インデックスの信頼幅は，採集 時期ごとに異なるので，消長曲線の信頼幅も採集時期ご とに変化すると考えなければならない，現在のところ， 消長曲線の信頼性について多く論じられていないが，消 長曲線の信頼録界を trap index の信頼限界から考える ことはできそうである。

4. Williams' mean

このように変動が大きい資料の整理に際しては，デー タの幾何平均をとるいわゆる Williams' mean ${ }^{311}$ による 整理が行なわれる．Bidlingmayer5)は，トラップによる 採集結果を検討する場合，Williams' mean をとる妥当 性とその方法について詳しく論じている。この方法は trap index など採集個体数の 統計的処理に適している と思われるので，今後の研究に活用されるべきと思われ る.しかし，日本脳炎ウイルスの動向を知るためには， 平滑化した消長曲線を得るに止まらず，日々の変動を正 
確にとらえることも必要であるので, 変動の直接の原因 を追求する努力を忘れてはならないと思われる。

\section{VI. 調査対象個体群の選定}

調查対象の集団と採集方法を設定した場合, 上に述べ た諸問題の解決が必要であるが，それ以前に，何を調查 対象の集団とすべきかということに注意が払われるべき である.この点を正面から取り上げた論文はまだだされ ていないと思われるが，採集方法が違え滛集された集 団の様相が異なるから，たとえば，日本脳炎患者発生に ついて考える場合，豚舎における蚊採集データだけでよ いかどうか問題である。比較的近接した豚舎と人家での 採集蚊消長の比較12)などについても今後より深く考える 必要がある，豚舎における蚊集団の変動は，豚間の日本 脳炎流行の説明には適していても，患者の動向の説明に は不適当であるかもしれないからである.

\section{VII.あとがき}

以上，蚊の採集方法，採集結果の検討方法，その有用 性などについて，日頃考えていることを覚え書き程度に まとめてみた，個々の問題について詳細に論ずることは できなかつたが，このように考えると，蚊のように比較 的研究対象としての歷史が古いものであつても，わから ないことが多いことに気がっく，一方において，蚊の個 体群動向については, 教科書的定説もあつて,これが真の 個体群動向を生のデータから求めようとする動機に水を きすような結果となつていることも否定できない，今後 の日本脳炎ウイルスの生態解明に役立つ蚊の研究には, 既成の概念からしばらく離れて, 明確な目的意識の下に, 信頼性の高い資料を集積しなおすことが必要であろう。

\section{文献}

[第 1 部]

1) Barnett, H. C. (1967) : Jap. J. Med. Sci. Biol. 20, 19-21.

2) Bram, R. A. (1967) : Contr. Am. Ent. Soc. 2, 230-232.

3) Cates, M. D. and Huang, W. C. (1969): Mosq. News 29, 620-623.

4) Chamberlain, R. W. and Sudia, W. D. (1961) : Ann. Rev. Ent. 6, 371-390.

5) Collins, W. E. (1964) : Mosq. News 24, 2527.

6) Diercks, F. H. and Hammon, W. $\mathrm{McD}$ (1958): Proc. Soc. Exp. Biol. Med. 97, 627-632.

7) Doi, R. et al. (1967) : Jap. J. Exp. Med. 37, 227-238.

8) Edman, J. D. et al. (1972) : Am. J. Trop. Med. Hyg. 21, 487-491.
9) Gould, D. J. et al. (1965) : Proc. XIIth Intern. Congr. Ent. 770.

10) Gresser, I. et al. (1958) : Jap. J. Exp. Med. $28,243-248$.

11) 林, 山本 (1964) : 衛生動物, 15, 105.

12) Janzen, H. G. et al. (1970) : Canad. J. Microbiol. $16,581-586$.

13) Jupp, P. G. et al. (1966) : S. Afr. J. Med. Sci. 31, 51-53.

14）上村, 松田 (1972)：富山目農村医学研究誌，3, 66-86.

15）唐牛, 他 (1972)：第20回日本ウイルス学会総会 講演予稿集, 2001 .

16) LaMotte, L. C. Jr. (1960) : Am. J. Hyg. 72, 73-87.

17) LaMotte, L. C. Jr. (1963) : Mosq. News 23, 330-335.

18) Macdonald, W. W. et al. (1967) : J. Med. Ent. 4, 146-157.

19）前田，竹の熊 (1973)：衛生動物， 23，288.

20) 宮城一郎 (1972) : Trop. Med. 14, 203-217.

21）奈須, 他 (1966) : ウイルス, 16, 35-36.

22) Okuno, T. et al. (1971) : Bull. WHO 44, 599-604.

23) Richardson, M. W. (1972) : J. Med. Ent. 9, 495-500.

24）佐多学 (1971)：衛生動物，22，181-186.

25) Scherer, W. F. et al. (1959) : Am. J. Trop. Med. Hyg. 8, 665-677.

26) Shirasaka, A. et al. (1968) : Jap. J. Exp. Med. 38, 423-435.

27) Sulkin, S. E. et al. (1970) : Am. J. Trop. Med. Hyg. 19 : 77-87.

28) 高橋三雄 (1967) : 神経研究の進歩, 11，215-222.

29) Takahashi, M. et al. (1969) : Jap. J. Med. Sci. Biol. 22, 163-174.

30) Takahashi, M. et al. (1971) : Jap. J. Med. Sci. Biol. 24, 163-169.

31）高橋三雄 (1971)：衛生動物， 22，87-88.

32) Tempelis; C. H. and Reeves, W. C. (1962) : Am. J. Trop. Med. Hyg. 11, 294-297.

33) Tempelis, C. H. and Lofy, M. F. (1963) : Am. J. Trop. Med. Hyg. 12, 825-831.

34）和田義人 (1972)：Trop. Med. 14, 41-54.

35）和田義人 (1972)：Trop. Med. 14, 151-163.

36) Weiz, B. (1956) : Bull. WHO 15, 473-490.

37) Whitfield, S. G. et al. (1971) : Virology 43, 110-122.

38）山本英穂(1971)：衛生動物学の進歩，第 1 集, $77-103$.

[第 2 部]

1) Barr, A. R. et al. (1960) : Jour. Econ. Ent., 53, 876-880.

2) Barr, A. R. et al. (1963) : Jour. Econ. Ent., 56, 123-127.

3) Bidlingmayer, W. L. (1964) : Ecology, 64, 
87-94.

4) Bidlingmayer, W. L. (1967) : J. Med. Ent., 4, 200-220.

5) Bidlingmayer, W. L. (1969) : Mosq. News, 29, 635-640.

6) Breeland, S. G. and Pickard, P. E. (1965) : Mosq. News, 25, 19-21.

7) Buescher, E. L. et al. (1959) : Am. J. Trop. Med. \& Hyg., 8, 651-664.

8) Hayes, R. O. et al. (1958) : Mosq. News, 18, 218-227.

9) 石田, 他 (1969)：日本細菌学雑誌， 24，373-379.

10）石井(1971a)：京都府衛研年報，16，51-54.

11）石井 (1971b)：京都府衛研年報， 16,55-62.

12）石井 (1972) : 京都府衛研年報, 17，49-57.

13）上村, 香取 (1969) : 衛生動物, 20, 87-94.

14）今野 (1967)：東北のコロニー, 15, 31-57.

15）唐牛, 他 (1970)：医学のあゆみ, 74:648-650.

16) 加藤, 他 (1951) : 生態学研究, 12, 52-55.

17) 加藤, 他 (1966) : 衛生動物, 17, 83-88.

18）加藤，他 (1967) : 衛生動物， 18, 218-239.

19) Khan, A. A. et al. (1971) : J. Med. Ent., 8, 41-43.

20) Loomis, E. C. and S. G. Hanks (1959) : Mosq. News, 19, 168-171.

21) Miller, T. A. et al. (1970) : J. Med. Ent., 7, 555-561.
22) 三田村, 他 (1940)：日本医学及健康保険, 3208, 743-745.

23) Morris, C. D. and G. R. DeFoliart (1969) : Mosq. News, 29, 424-426.

24) 大谷 (1971)：日本脳炎ウイルス生態学研究会会 報， 2,3-4.

25) Reeves, W. C. (1953) : Amer. J. Trop. Med. \& Hyg., 2, 325-331.

26) Service, M. W. (1969) : Ent. exp. \& appl. 12, 403-412.

27）清水，他 (1969)：衛生動物， 20, 76-80.

28) Taylor, D. J. et al. (1966) : Mosq. News, 26, 502-506.

29) Vickery, C. A. Jr. et al. (1966) : Mosq. News, 26, 507-508.

30）和田 (1970)：衛生動物， 21，54-60.

31) Williams, C. B. (1951) : Bull. ent. Res., 42, 513-517.

32) Wright, R.E. and K. L. Knight (1966) : Mosq. News, 26, 565-578.

33）山田(1933)：東京医学会雑誌，48，176-183.

34) 山田 (1934)：医学公論, 1122, 5-7.

35) 山本 (1971) : 衛生動物の進歩, 第 1 集, 77-103.

36) 山口 (1950): 最近の生物学, 第 1 巻, 134-157.

37) Yajima, T. (1973) : Sci. Rep. Tôhoku Univ. Ser. IV (Biol.), 36, 241-253. 